\title{
AKTIVITAS HARIAN LUTUNG JAWA (Trachypithecus auratus sondacius) DI KAWASAN TAMAN BURU MASIGIT KAREUMBI JAWA BARAT
}

\author{
Doni Sontono $^{1}$, Ana Widiana² dan Sekarwati Sukmaningrasa ${ }^{3}$. \\ 1, 2,3 Jurusan Biologi , Fakultas Sains dan Teknologi \\ Universitas Islam Negeri Sunan Gunung Djati Bandung
}

Diterima :07 Juni 2016 Ditinjau :14 Oktober 2016 Disetujui :01 November 2016

\begin{abstract}
Abstrak. Lutung Jawa (Trachypithecus auratus sondaicus) merupakan salah satu bagian dari total keanekaragaman hayati Indonesia yang terdegradasi secara terus menerus disebabkan oleh kehilangan habitat dan perburuan liar. Taman Buru Gunung Masigit Kareumbi merupakan salah satu kawasan yang banyak dihuni oleh primata, yang salah satunya adalah Lutung Jawa. Primataprimata yang berada di kawasan ini khususnya Lutung Jawa selalu di buru oleh pemburu liar yang diperuntukan untuk dijual belikan bahkan digunakan untuk obat-obatan oleh pihak-pihak yang tidak bertanggung jawab terhadap keberadaan jenis primata ini. Taman Buru Gunung Masigit Kareumbi terletak di Kabupaten Garut, Sumedang dan Bandung dengan luas 12,420,70 ha. Tujuan Penelitian ini adalah untuk mengetahui aktivitas harian Lutung Jawa di Kawasan Taman Buru Gunung Masigit Kareumbi Jawa Barat. Metode yang digunakan dalam pengamatan ini adalah menggunakan metode Adlibitum untuk mencatat setiap perilaku yang dikerjakan atau teramati selama penelitian dan metode scan sampling yaitu pencatatan aktivitas satwa seluruh individu dalam kelompok dengan menggunakan interval waktu, Analisis data pada penelitian ini menggunakan metode deskriptif. Hasil penelitian aktivitas harian Lutung Jawa yang berada di Taman Buru Masigit Kareumbi yang memiliki titik koordinat 06'94'36' LS dan 107'93'95 ' BT dan berada pada ketinggian 1,259 mdpl ini menunjukan bahwa aktivitas harian yang sering dilakukan adalah aktivitas lokomosi yaitu dengan persentase keseluruhan sebesar 25,20\%, sedangkan untuk aktivitas terendahnya adalah aktivitas urinasi dengan persentase sebesar 1,94\%.
\end{abstract}

Kata Kunci : Lutung Jawa (Trachypithecus auratus sondaicus), Gunung Masigit Kareumbi Jawa Barat, metode adlibitum dan scan sampling, aktivitas.

\begin{abstract}
Java langur (Trachypithecus auratus sondaicus) is one part of the total biodiversity of Indonesia is continuously degraded due to loss of habitat and poaching. Hunting Park Mount Masigit Kareumbi is one area that was inhabited by primates, one of which is a Java monkey. Primates are in the region especially Java monkey is always in hurry by poachers who intended to dijualbelikan even used for medicine by parties who are not responsible for the existence of this primate species. Hunting Park Mount Masigit Kareumbi located in Garut, Sumedang and Bandung with extensive $12.420 .70 \mathrm{ha}$. The study objective was to determine the daily activities in the Java monkey Hunting Park area of Mount Masigit Kareumbi West Java. The method used in this observation is adlibitum method to record any behavior that done or observed during the study and scan sampling methods that record all activity of individual animals within a group by using a time interval, Analysis of the data in this study using descriptive methods. The results Javanese monkey daily activities that are in Hunting Park Masigit Kareumbi which has the coordinates 06 $94^{\prime} 36$ ' $L S$ and $107^{\circ} 93^{\prime} 95^{\prime}$ 'BT and an altitude of 1,259 $\mathrm{m}$ above sea level shows that daily activity is often done with the locomotion activity overall percentage of $25.20 \%$, while the lowest activity was urinary activity with a percentage of $1.94 \%$.

Keywords: Java monkey (Trachypithecus auratus sondaicus), Mount Masigit Kareumbi West Java, adlibitum and scan sampling methods, activities.
\end{abstract}

\section{PENDAHULUAN}

Lutung Jawa merupakan jenis primata endemik Pulau Jawa dan Bali yang populasi dan habitatnya semakin memprihatinkan. Akibat kehidupannya yang terisolasi, tidak menutup kemungkinan Lutung Jawa akan mengalami stres yang akan mempengaruhi 
kemampuannya untuk bereproduksi. Habitat Lutung Jawa meliputi hutan primer, hutan sekunder, hutan pantai, hutan mangrove maupun hutan hujan tropis. Lutung Jawa memiliki daerah jelajah yang cukup luas sehingga memerlukan koridor untuk pergerakannya. Menurut Supriatna dan Wahyono (2000 dalam Anonim, 2005), daerah jelajah Lutung Jawa berkisar antara 15-23 ha. Sedangkan menurut Clutton-Brock and Harvey (1977 dalam Nursal 2001), primata yang hanya memakan daun akan memiliki daerah jelajah dan bentuk tubuh yang kecil dibandingkan dengan primata yang memakan beranekaragam seperti daun, bunga dan buah. Lutung Jawa adalah salah satu satwa liar yang dilindungi, hal ini sesuai dengan SK Menteri Kehutanan dan Perkebunan No. 733 / kpts-II / 1999 dan tercantum dalam Appendix II CITES. IUCN (International Union for Conservation of Nature and Natural Resource) yang menyatakan bahwa status konservasi Lutung Jawa adalah vulnerable, yang artinya rentan terhadap gangguan dan dikhawatirkan akan punah apabila tidak dilakukan perlindungan dan pelestarian habitatnya (IUCN, 2012). Selain itu primata yang tergolong endemik ini juga dilindungi oleh UU Nomor 5 tahun 1990 tentang Konservasi Sumber Daya Alam Hayati dan Ekosistemnya, satwa langka tersebut tidak boleh diperjualbelikan (Pratiwi, 2008).

Taman Buru ini secara administratif terletak di Kabupaten Garut, Sumedang dan Bandung. Terdapat berbagai jenis fauna yang terdapat di Taman Buru Gunung Masigit Kareumbi seperti ayam hutan (Gallus galus sp.), babi hutan (Sus cropiatus), bunglon (Conyephalus dilophus), kukang (Nyctiebus coucang), monyet ekor panjang (Macaca fascicularis), lutung jawa (Trachypithecus auratus sondaicus), macan tutul (Panthera tigris) dan lain-lain. Lutung Jawa merupakan jenis hewan arboreal yaitu hewan yang beraktivitas di pohon. Rata-rata jumlah dalam satu kelompok sekitar tujuh individu. Febriyanti (2008) menemukan bahwa bentuk kelompok Lutung Jawa terdiri dari 6-21 individu dengan satu atau dua jantan dewasa. Predator utama primata ini adalah manusia yang memburu jenis ini untuk komersial dan kebutuhan makanan. Lutung Jawa mempunyai panjang tubuh dari ujung kepala sampai tungging (jantan dan betina dewasa) rata-rata $517 \mathrm{~mm}$ dan panjang ekornya ratarata $742 \mathrm{~mm}$. Sedangkan berat tubuhnya ratarata $6,3 \mathrm{~kg}$. Warna rambut hitam, diselingi dengan warna keperak-perakan, sedangkan untuk anak yang baru lahir berwarna kuning jingga. Setelah meningkat dewasa warnanya berubah menjadi hitam kelabu. Perbedaan antara jantan dan betina secara morfologi terletak pada perkembangan alat kelamin sekunder, sedangkan untuk kelompok umur pada Lutung Jawa dibedakan berdasarkan ukuran tubuh dan aktivitas hariannya. Pada jantan dewasa mempunyai ukuran tubuh relatif besar sedangkan pada betina dewasa memiliki ukuran tubuh lebih kecil atau hampir sama dengan ukuran jantan dewasa. Pada lutung betina rambut bagian punggung lebih hitam dari pada warna punggung lutung jantan (Nugraha, 2011).

Lutung Jawa memulai aktivitasnya sejak dari bangun tidur yaitu sekitar pukul 05:30 WIB, kemudian berpindah untuk makan di pohon sumber pakan di sekitar pohon tempat tidur. Akhir dari aktivitas harian ditandai dengan adanya aktivitas berpindah memasuki pohon tempat tidur, untuk memasuki pohon tempat tidurnya yaitu sekitar pukul 18.00 WIB (Andriansyah, 2007). Lutung Jawa mempunyai jalur-jalur tertentu dalam menempuh perjalanan harian, mencari makan dan tempat tidurnya, tiga strata pohon secara vertikal untuk tempat tidurnya yaitu bagian pucuk kanopi, ditengah-tengah pohon dan di bawah pohon, sedangkan untuk aktivitas perjalanan harian dan mencari makan, ruang habitat secara vertikal dibagi empat strata yaitu puncak kanopi, tengah-tengah pohon, di bawah pohon dan di lantai hutan (Latifah 2002 dalam Nugraha 2011). Keberadaan Lutung Jawa di Indonesia merupakan jenis primata yang dilindungi. Status dilindungi tersebut berdasarkan Keputusan Menteri Kehutanan dan Perkebunan Nomor : 733 / Kpts-II / 1999 tentang Penetapan Lutung Jawa sebagai Satwa yang dilindungi. Salah satu pertimbangan dalam penetapan status dilindungi ini karena populasi jenis satwa ini telah mengalami penurunan dan keberadaannya di alam terancam punah (Subagio, 2008). 


\section{BAHAN DAN METODE}

Penelitian ini dilaksanakan di Kawasan Taman Buru Gunung Masigit Kareumbi. Spot penelitian berada di kawasan Cigumentong, Desa Sindulang, kecamatan Cimanggung, kabupaten Sumedang. Spot penelitian didasarkan pada seringnya Lutung Jawa berada di daerah tersebut, spotpertama ini terletak pada titik koordinat $06^{0} 94^{\prime} 36$ LS dan $107^{0} 93^{\prime} 95$ BT dengan ketinggian 1259 mdpl dan luas area penelitian \pm 15 Ha. Spot penelitian kedua terletak pada titik koordinat 06 $94^{\prime} 86^{\prime \prime}$ LS dan $107^{\circ} 92^{\prime} 46^{\prime}$ 'BT dengan ketinggian 1191 mdpl dan luas \pm 5 ha. Jarak dari spot Gunung Masigit Kareumbi sekitar 9 Km. Penelitian ini dilakukan dari bulan Maret sampai dengan bulan April 2012. Alat dan Bahan yang digunakan alat tulis, teropong, kompas, GPS, termometer basah kering dan buku panduan jenis flora dan fauna.Metode yang digunakan dalam pengamatan ini adalah menggunakan metode Adlibitum untuk mencatat setiap perilaku yang dikerjakan atau teramati selama penelitian yang digabungkan dengan metode scan sampling yaitu pencatatan aktivitas individu dalam kelompok dengan menggunakan interval waktu (Altman, 1974 dalam Fuadi, 2008).

Pengamatan dilakukan di Taman Buru Gunung Masigit Kareumbi Jawa Barat tepatnya di daerah Cigumentong dengan mengamati secara langsung Lutung Jawa yang berada di daerah tersebut, pengamatan ini menggunakan metode Adlibitum untuk mencatat setiap perilaku yang dilakukan. Parameter yang diamati adalah makan, lokomosi, grooming, bermain, urinasi, suara dan istirahat. Pengamatan ini dilakukan dari pukul 06.00 WIB sampai dengan 16.30 WIB dengan interval waktu pengamatan setiap 30 menit sekali. Pencatatan suhu dan kelembaban dilakukan pada pagi pukul 06.00 WIB, siang pada pukul $12.00 \mathrm{WIB}$, dan sore hari pada pukul 16.30 WIB, hal ini disebabkan karena keadaan suhu dan kelembaban udara lingkungan merupakan faktor yang sangat mempengaruhiaktivitas pada Lutung Jawa. Karakteristik Lutung Jawa pada saat pengamatan di Taman Buru Masigit Kareumbi berumur $\pm 5-7$ tahun dengan total jumlah \pm 12 individu dari satu kelompok Lutung Jawa.
Data yang diperoleh dari pengamatan di lapangan dipaparkan menggunakan metode deskriptif kualitatif yang merupakan analisa non-statistik. Data yang terhimpun diuraikan dalam bentuk kalimat penjelasan dengan bantuan tabel, diagram maupun gambar. Rumus persentase aktivitas setiap individu adalah :

A/B X $100 \%$

Keterangan :

$\mathrm{A}=$ Rata-rata aktivitas yang diamati dalam perlakuan

$\mathrm{B}=$ Total semua aktivitas yang diamati.

\section{HASIL}

\section{Aktivitas Lutung Jawa}

Taman Buru Gunung Masigit Kareumbi, merupakan salah satu kawasan yang banyak dihuni oleh primata, yang salah satunya adalah Lutung Jawa. Primata-primata yang berada di kawasan ini khususnya Lutung Jawa selalu diburu oleh pemburu liar yang diperuntukan untuk diperjual belikan bahkan digunakan untuk obat-obatan oleh pihak-pihak yang tidak bertanggung jawab terhadap keberadaan jenis primata ini. Selama pengamatan Lutung Jawa yang berada di kawasan ini juga hanya memiliki jumlah individu dari kelompok \pm 12 , hal ini mengindikasikan primata yang berada di kawasan ini sudah hampir dan bahkan akan punah. Hal ini dikarenakan selama pengamatan terlihat sering kali adanya perburuan dan bahkan terlihat individu Lutung Jawa yang sudah mati tergeletak di tanah dan hanya menyisakan kulit saja. Pengamatan aktivitas Lutung Jawa yang dilakukan di Taman Buru Masigit Kareumbi memperlihatkan bahwa Lutung Jawa memulai aktivitas hariannya dengan melakukan aktivitas berpindah dari pohon tempat tidurnya ke pohon lain (lokomosi), tidak jarang juga terlihat Lutung Jawa memulai aktivitas hariannya dengan melakukan aktivitas membersihkan diri (grooming) sambil dudukduduk di dahan pohon yang ditempatinya. Biasanya rataan kebiasaan membersihkan diri ini dilakukan selama sekitar 5-10 menit sebelum melakukan aktivitas lain/ Total frekuensi aktivitas harian Lutung Jawa yang berada di Taman Buru Masigit Kareumbi dapat dilihat pada gambar di bawah: 


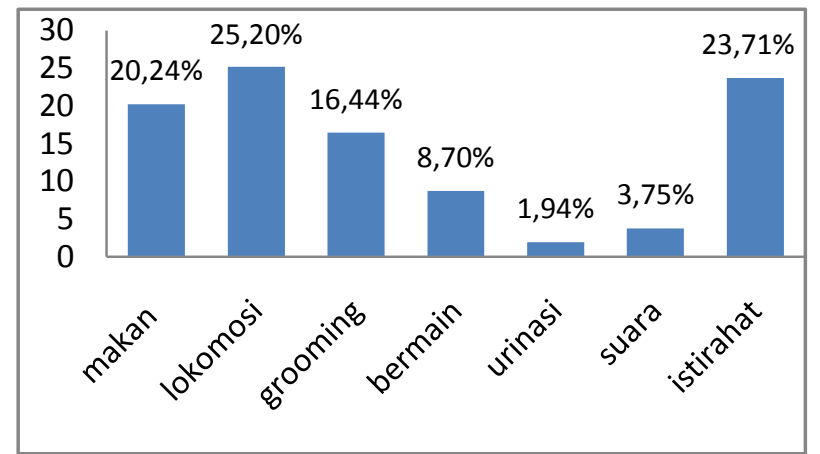

Gambar 1. Persentase aktivitas Lutung Jawadi Taman Buru Masigit Kareumbi

Gambar di atas menunjukkan bahwa frekuensi aktivitas Lutung Jawa yang ada di Taman Buru Masigit Kareumbi yang paling tinggi adalah aktivitas lokomosi yaitu sebesar $25,20 \%$, persentase aktivitas yang tinggi selanjutnya diikuti oleh aktivitas istirahat (23,71) dan aktivitas makan (20.24). Sedangkan untuk persentase aktivitas yang paling rendah adalah aktivitas urinasi yaitu sebesar $1,94 \%$

\section{Aktivitas Lokomosi}

Dari hasil pengamatan terhadap aktivitas lokomosi yang dilakukan di Taman Buru Masigit Kareumbi, aktivitas lokomosi merupakan aktivitas yang paling sering dilakukan oleh Lutung Jawa yang berada di kawasan tersebut yaitu dengan rataan persentase sebesar 25,20\%. Tingginya aktivitas ini terlihat saat Lutung Jawa banyak melakukan gerakan berpindah dari satu tempat ke tempat lain untuk mencari pakan. Hasil pengamatan lokomosi Lutung jawa dapat dilihat pada gambar berikut:

Gambar 2 menunjukkan bahwa aktivitas lokomosi mencapai puncaknya pada pukul 13.30-14.30 WIB.

\section{Aktivitas Istirahat}

Istirahat adalah aktivitas (keadaan) tidak melakukan kegiatan (diam), keadaan ini biasanya dalam posisi duduk, menelungkup dan terlentang. Hasil pengamatan keseluruhan aktivitas istirahat Lutung Jawa adalah sebesar $23,71 \%$, aktivitas ini adalah aktivitas tertinggi kedua setelah aktivitas lokomosi. Hal ini dikarenakan Lutung Jawa sangat memerlukan istirahat untuk menstabilkan kondisi tubuh (fisik) setelah melakuan aktivitas lokomosi

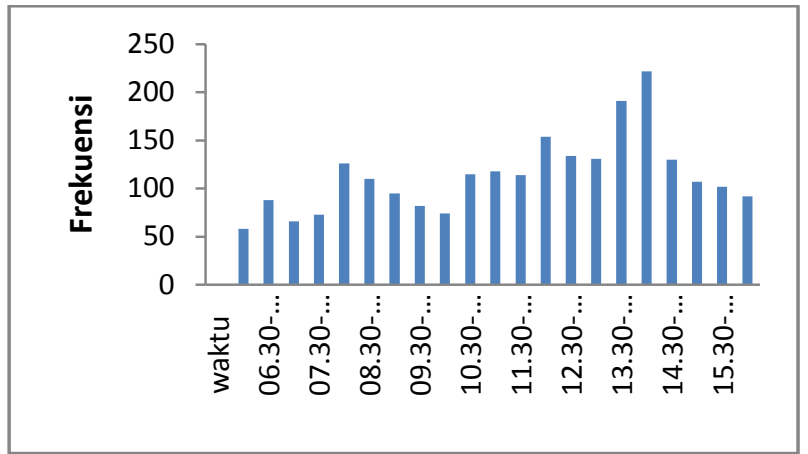

Gambar 2. Aktivitas lokomosi Lutung Jawa di Taman Buru Masigit Kareumbi

untuk mencari makan atau aktivitas lain.Hasil pengamatan aktivitas istirahat Lutung Jawa dapat dilihat pada gambar di bawah ini, dimana aktivitas istirahat mencapai puncaknya terjadi pada pukul 14.00-14.30 WIB.

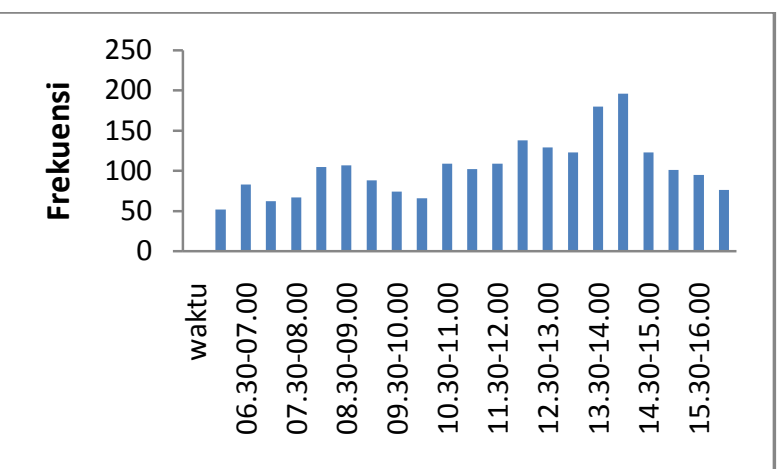

Gambar 3. Aktivitas istirahat Lutung Jawa di Taman Buru Masigit Kareumbi

\section{Aktivitas Makan}

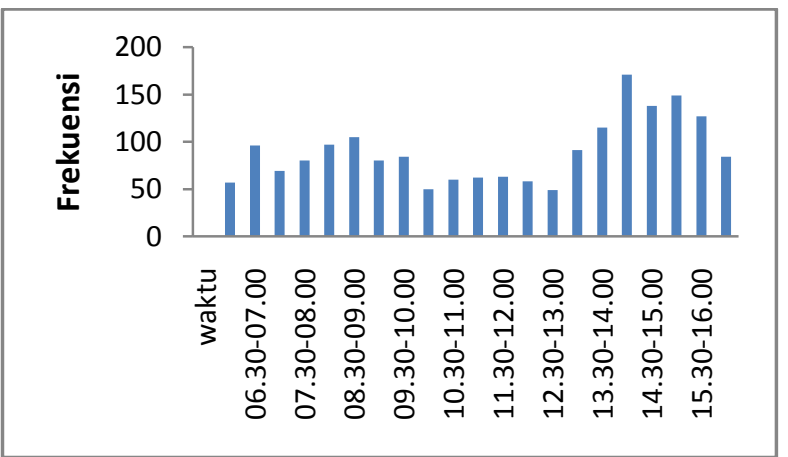

Gambar 4. Aktivitas makan Lutung Jawa di Taman Buru Masigit Kareumbi

Aktivitas makan adalah aktivitas yang meliputi pencarian makan, pemilihan pakan, memasukkan ke mulut, mengunyah dan di ikuti dengan menelan (Nursal, 2001). Total keseluruhan persentase aktivitas makan selama pengamatan mencapai 20,24\%, frekuensi makan yang cukup tinggi diduga karena pohon 
tempat pakan di tempat pengamatan sedang dalam kondisi berbuah, sehingga pakan yang dibutuhkan cukup melimpah menyebabkan Lutung Jawa mudah mendapatkan pakannya. Aktivitas makan mulai terlihat tinggi dari pagi hari sekitar pukul 07.00-09.00 WIB.

\section{Aktivitas Grooming}

Aktivitas membersihkan diri atau merawat diri dari kotoran dan parasit yang dilakukan dengan cara mengusap, meraba, menelisik, menggaruk, menjilat dan menggigit disebut dengan (Grooming). Menurut Prayogo (2006), aktivitas grooming dibedakan menjadi dua macam, yaitu autogrooming dan allogrooming. Autogrooming yaitu merawat diri yang dilakukan sendiri, sedangkan allogrooming adalah merawat diri yang dilakukan bersama individu lain. Aktivitas grooming yang terlihat selama pengamatan yang dilakukan di Taman Buru Gunung Masigit Kareumbi adalah aktivitas Autogrooming, hal ini dikarenakan pada saat pengamatan tidak terlihat ada banyak individu Lutung Jawa lain yang bersamaan dalam satu pohon. Hasil pengamatan aktivitas grooming dapat dilihat pada gambar berikut:

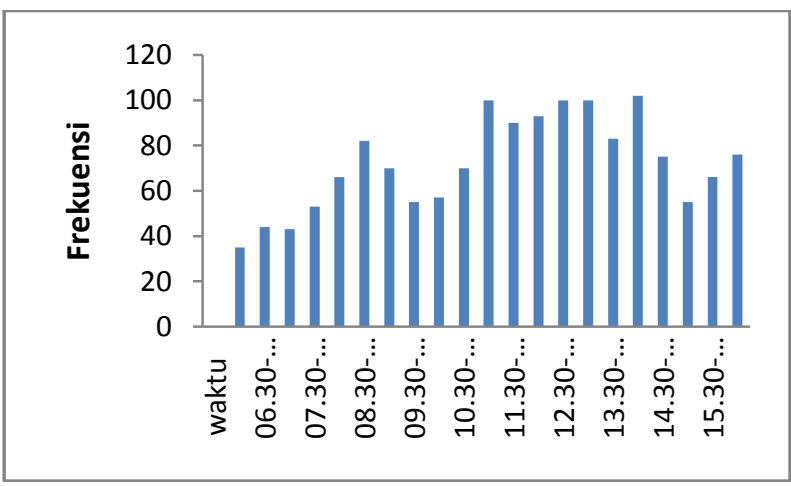

Gambar 5. Aktivitas grooming Lutung Jawa di Taman Buru Masigit Kareumbi

Pengamatan Aktivitas grooming pada Lutung Jawa mencapai puncaknya terjadi pada pukul 14.00-14.30 WIB. Ini dikarenakan pada waktu tersebut Lutung Jawa akan sering melakukan aktivitas yang mempengaruhi aktivitas grooming seperti aktivitas istirahat dan bahkan terlihat melakukan aktivitas grooming sambil melakukan aktivitas makan. Frekuensi terendahnya terjadi pada saat pagi hari, karena pagi hari biasanya dilakukan Lutung Jawa untuk melakukan aktivitas lokomosi yang bertujuan untuk melakukan pencarian tempat pakan. Persentase aktivitas grooming lebih rendah dari aktivitas istirahat yaitu $16,44 \%$. Selain terlihat duduk untuk melakukan grooming. Lutung Jawa yang berada di Taman Buru Masigit Kareumbi ini juga biasanya melakukan grooming seperti menjilati bulunya dan tidak jarang juga terlihat menggaruk-garuk tubuhnya.

\section{Aktivitas Bermain}

Hasil pengamatan aktivitas bermain di Taman Buru Masigit Kareumbi dapat dilihat pada gambar berikut:

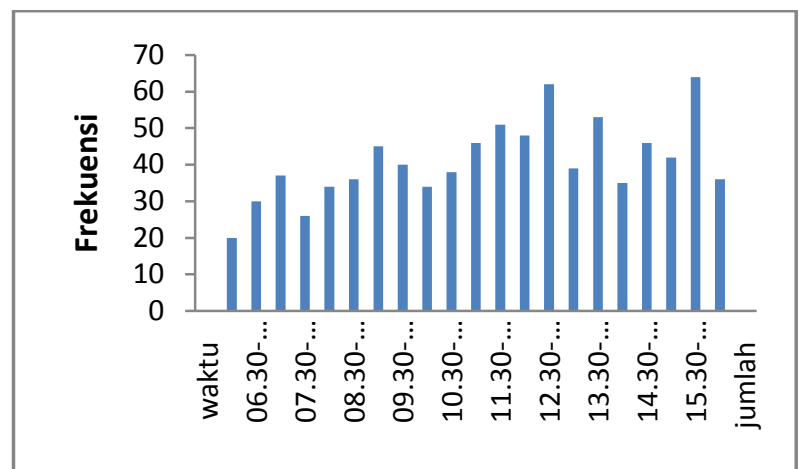

Gambar 6. Aktivitas bermain Lutung Jawa di Taman Buru Masigit Kareumbi

Aktivitas bermain yang dilakukan Lutung Jawa mencapai puncaknya terjadi pada siang hari antara pukul $11.30 \mathrm{WIB}$ dan pada sore hari antara pukul 15.30 WIB.

\section{Aktivitas Bersuara}

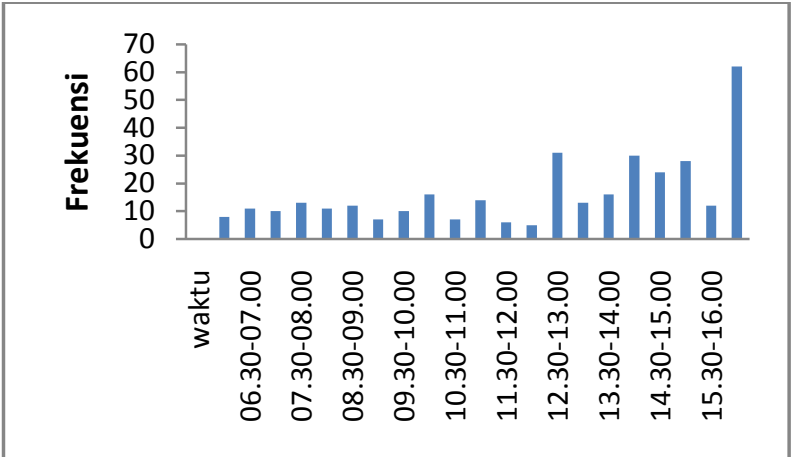

Gambar 7. Aktivitas bersuara Lutung Jawa di Taman Buru Masigit Kareumbi

Bersuara merupakan salah satu cara Lutung Jawa untuk berkomunikasi. Ketua kelompok dari Lutung Jawa mempunyai peranan yang sangat besar dalam melakukan vokalisasi, karena memiliki tempo suara yang tinggi. Aplikasi sosial vokalisasi dilakukan sebagai penandaan daerah teritori, posisi 
individu menemukan daerah tempat makanan dan keadaan tertentu seperti bahaya atau dalam posisi terancam (Fuadi, 2008). Hasil pengamatan aktivitas bersuara Lutung Jawa di Taman Buru Masigit Kareumbi dapat dilihat pada gambar 7 .

Dari gambar di atas menunjukkan bahwa aktivitas bersuara mencapai puncaknya pada pukul 16.00-16.30, hal ini dikarenakan pada waktu tersebut Lutung Jawa khususnya ketua dari kelompok akan memanggil anggota kelompoknya untuk kembali ke pohon tempat tidurnya. Aktivitas ini adalah aktivitas terendah kedua selama pengamatan, ini dikarenakan selama pengamatan Lutung Jawa yang berada di Taman Buru Masigit Kareumbi hanya bersuara pada sore hari yang menandakan (bertujuan) untuk memanggil seluruh anggota kelompoknya untuk kembali ke tempat bersarangnya.

\section{Aktivitas Urinasi}

Urinasi adalah aktivitas membuang kotoran yang berbentuk cair. Hasil pengamatan aktivitas urinasi Lutung jawa di Taman Buru Masigit Kareumbi dapat dilihat pada gambar berikut:

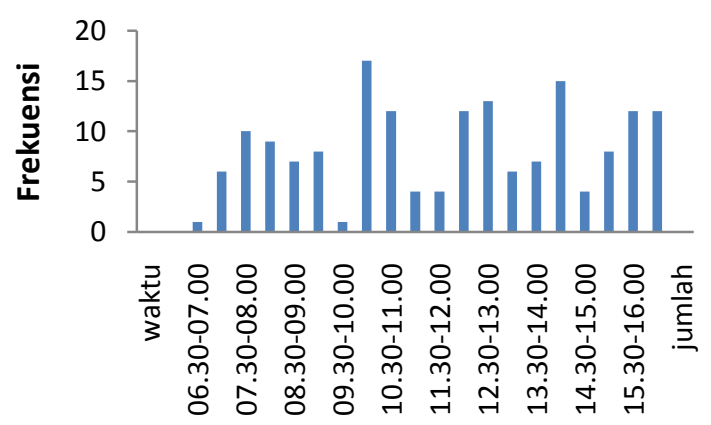

Gambar 8. Aktivitas urinasi Lutung Jawa di Taman Buru Masigit Kareumbi

Dari gambar di atas menunjukan bahwa aktivitas urinasi mencapai puncaknya pada pukul 10.00-10.30, tingginya aktivitas urinasi pada jam tersebut dikarenakan konsumsi air yang ada pada buah-buahan yang dimakan pada pagi hari sangat tinggi.

\section{PEMBAHASAN}

Secara keseluruhan, aktivitas Lutung Jawa di Taman Buru Masigit Kareumbi dipengaruhi oleh beberapa faktor. Aktivitas tertinggi pada hasil pengamatan yaitu lokomosi, seperti yang dinyatakan Permadi (2012) bahwa tingginya aktivitas lokomosi di alam bebas dipengaruhi oleh keberadaan pakan yang melimpah di daerah jelajahnya (home range). Kondisi ini juga sesuai dengan pernyataan Hendratmoko, (2009) yang menyatakan bahwa Lutung Jawa yang berada di alam banyak menghabiskan waktunya untuk makan dan istirahat di alam. Sedangkan untuk persentase aktivitas yang paling rendah adalah aktivitas urinasi. Kondisi ini disebabkan karena di alam bebas Lutung Jawa jarang teramati melakukan aktivitas minum, dan kebutuhan air dalam tubuh biasanya didapat dari kandungan air yang cukup rendah yang ada di buah-buahan yang dimakan.

Aktivitas lokomosi mencapai puncaknya pada pukul 13.30-14.30 WIB. Hal ini dikarenakan pada jam tersebut Lutung Jawa akan banyak melakukan pergerakan untuk mencari persediaan pakan dan mencari tempat untuk beristirahat. Menurut Fuadi (2008) aktivitas lokomosi di alam bebas akan mencapai persentase sebesar $27 \%$, sedangkan menurut Prayogo (2006) hasil pengamatan lokomosi di penangkaran adalah sebesar 9,51\%. Perbedaan antara hasil yang didapat dari pengamatan yang dilakukan di alam dan di penangkaran tersebut dikarenakan ruang lingkup di alam bebas yang menyebabkan Lutung Jawa akan lebih banyak melakukan pergerakan sedangkan untuk yang di penangkaran, terbatasnya ruang gerak akan mengakibatkan Lutung Jawa sulit untuk melakukan banyak pergerakan.

Pergerakan Lutung Jawa yang sering dilakukan di Taman Buru Masigit Kareumbi adalah jenis pergerakan eksplorasi, yaitu pergerakan menjelajahi daerah sekitar maupun berpindah untuk mencari dan memilih makanannya. Aktivitas Lutung Jawa sangat dipengaruhi oleh ketersediaan pakan yang melimpah di daerah jelajahannya, keadaan ini sesuai dengan yang dikemukakan Fuadi (2008), bahwa pergerakan satwa erat hubungannya dengan sifat individu dan kondisi lingkungan seperti ketersediaan pakan, fasilitas untuk berkembang biak, pemangsaan, kondisi cuaca, sumber air maupun adanya pengrusakan lingkungan. 
Aktivitas istirahat mencapai puncaknya terjadi pada pukul 14.00-14.30 WIB, tingginya aktivitas istirahat pada waktu tersebut disebabkan selain karena faktor suhu yang tinggi $\left(28,4^{\circ} \mathrm{C}\right)$ juga karena pada jam-jam sebelumnya Lutung Jawa lebih banyak melakukan aktivitas seperti lokomosi untuk mencari pakan sehingga aktivitas istirahat ini dilakukan untuk pengembalian kondisi tubuh. Waktu istirahat penting dilakukan oleh Lutung Jawa dan primata lainnnya untuk mencerna makanan yang telah dikonsumsinya.

Menurut hasil pengamatan Prayogo (2006) hasil aktivitas istirahat di Taman Marga Satwa Ragunan menunjukan bahwa aktivitas istirahat memiliki persentase tertinggi yaitu sebesar $25,94 \%$. Hal serupa juga dibahas oleh Wirdateti, et al (2009), bahwa Lutung Jawa yang berada di penangkaran memiliki persentase aktivitas istirahat yang tinggi dari aktivitas lainnya. Dari hasil pengamatan yang dilakukan di Taman Buru Masigit Kareumbi, Lutung Jawa memiliki aktivitas istirahat yang cukup tinggi yaitu sebesar $23,71 \%$. Persamaan aktivitas istirahat yang dilakukan di alam bebas dengan yang di penangkaran ini karena Lutung Jawa yang berada di alam, selain karena faktor suhu yang tinggi Lutung Jawa juga akan sangat memerlukan istirahat setelah melakukan penjelajahan untuk pencarian makanannya, sedangkan untuk yang di penangkaran Lutung Jawa jarang melakukan aktivitas lain selain aktivitas berpindah dari dahan satu ke dahan lain dan lebih sering melakukan aktivitas istirahat (diam).

Aktivitas makan mulai terlihat tinggi dari pagi hari sekitar pukul $07.00-09.00$ WIB. Hal ini dikarenakan saat pagi hari Lutung Jawa akan membutuhkan energi untuk memulai aktivitas lain yang akan dilakukan. Aktivitas makan mencapai puncaknya pada pukul 14.00 - 16.00 WIB, ini dikarenakan pada jam tersebut Lutung Jawa harus makan lebih banyak sebelum kembali ke pohon tempat tidurnya. Hal ini sesuai dengan pernyataan Ribby (2012) yang menyatakan bahwa puncak aktivitas makan Lutung Jawa di Taman Buru Masigit Kareumbi yaitu pada siang hari dikarenakan pada pagi hari hingga siang hari Lutung Jawa lebih banyak melakukan aktivitas lokomosi.
Tingkah laku makan Lutung Jawa yang berada di Taman Buru Masigit Kareumbi dimulai dengan melakukan pencarian tempat pakan, kemudian memilih-milih makanan yang ada (daun-daunan, buah-buahan bahkan biji-bijian) yang akan dimakan pada tempat (pohon) yang ditempati untuk makan. Menurut Permadi (2012), untuk aktivitas makan, Lutung Jawa memanfaatkan bagian tajuk dari vegetasi pinus yang mana bagian tajuk yang dimakan adalah daun-daun yang masih muda. Untuk mengambil daun-daun tersebut biasanya Lutung Jawa bergerak menuju bagian atas vegetasi dan biasanya mengambil bagian pucuk-pucuk daun.

Aktivitas bermain yang dilakukan Lutung Jawa yang berada di Taman Buru Masigit Kareumbi meliputi aktivitas berayunayun pada ranting, berlompat-lompatan, berkejar-kejaran dengan anggota kelompok lain dan tidak jarang juga terlihat Lutung Jawa melakukan permainan sendiri seperti mengibas-ngibaskan ekornya.

Perilaku bermain biasanya dilakukan oleh individu anak dan remaja baru dan dilakukan pada saat periode istirahat. Individu anak biasanya melompat-lompat, kejar mengejar dengan sesama individu anak yang lain. Individu remaja masih melakukan hal ini, yang melibatkan individu remaja lain atau individu anak lain. Perilaku ini bermanfaat untuk melatih kemampuan fisik dan koordinasi serta kemampuan berkopetensi sehingga individu anak dan remaja itu sudah siap menghadapi lingkungan (Nursal, 2001).

Dari keseluruhan hasil pengamatan, aktivitas urinasi adalah aktivitas yang paling rendah yaitu dengan rataan persentase sebesar 2\%. Hal ini dikarenakan Lutung Jawa yang berada di Taman Buru Masigit Kareumbi tidak terlihat banyak melakukan aktivitas minum, selain karena ketersediaan sumber air yang tidak terlihat selama pengamatan, di duga Lutung Jawa bisa mengganti kebutuhan air dalam tubuh dengan kandungan air yang ada pada buah-buahan yang dimakan. Hasil ini sesuai dengan pernyataan dari Ambarwati (1999 dalam Fuadi, 2008) yang menyatakan bahwa Lutung Jawa yang berada di alam bebas tidak terlalu membutuhkan banyak minum karena kebutuhan air dalam tubuh bisa diganti 
dengan kandungan air yang ada pada buahbuahan yang di makan.

Berdasarkan hasil dapat diketahui bahwa Aktivitas lokomosi adalah aktivitas yang paling banyak dilakukan oleh Lutung Jawa yang berada di kawasan tersebut yaitu dengan rataan persentase sebesar $25,20 \%$. Tingginya aktivitas ini dikarenakan Lutung Jawa banyak melakukan gerakan berpindah dari satu tempat ke tempat lain untuk mencari pakan. Aktivitas lokomosi yang sering terlihat selama pengamatan untuk berpindah dari satu pohon ke pohon lain yaitu dengan cara berjalan atau dengan cara bergelantungan.

Aktivitas terendah yang dilakukan oleh Lutung Jawa adalah aktivitas urinasi dengan persentase sebesar $1,94 \%$. Rendahnya aktivitas urinasi ini disebabkan selama pengamatan Lutung Jawa tidak terlihat melakukan aktivitas minum dan pencarian sumber air. Kebutuhan air diduga didapatkan dari kandungan air yang terdapat dalam buah-buahan dan daun-daunan yang dimakan.

Oleh karena itu erlu dilakukan penelitian tentang aktivitas harian Lutung Jawa (Trachypitecus auratus sondaicus) yang lainnya seperti pengamatan pengamatan aktivitas selama di sarang, termasuk aktivitas sexsual.

\section{DAFTAR PUSTAKA}

Andika, Marlin. 2011. Perilaku dan Pakan Lutung Kelabu (Trachypithecus cristatus, Raffles 1812) di Hutan Mangrove Kecamatan Gebang Kabupaten Langkat Provinsi Sumatera Utara. Skripsi. Universitas Sumatera Utara.

Andriansyah, Muhammad. 2007. Kegiatan Wisata Alam dan Keberadaan Lutung Jawa (Trachypthecus auratus Robinson dan Kloss 1919) sebagai Objek Ekowisata di Taman Wisata Alam Pananjung Pangandaran, Ciamis, Jawa Barat. Skripsi. Jurusan Biologi Fakultas Ilmu Pengetahuan Alam. Universitas Padjadjaran.

Anonim. 2005. Monitoring Keberadaan Lutung (Trachypithecus auratus cristatus) di Blok Kajang, Resort Bama Seksi Koservasi Wilayah Bekol. Bogor. Taman Nasional Baluran.
Anonim. 2009. Perilaku Harian Lutung (Trachypithecus cristatus, raffles 1812) di Penangkaran Pusat Penyelamatan Satwa Gadog, Ciawi-Bogor

Anonim. 2010. Aktivitas Fokal Lutung Kelabu di Kawasan Hutan Mangrove Kawala Gebang Kecamatan Gebang Kabupaten Langkat. Universitas Sumatera Utara.

Atmoko, Tri. 2010. Struktur Kelompok pada Primata. Final Report. Balai Penelitian Kehutanan Samboja. Kalimantan Timur.

Deni. 2010. Kajian Awal Terhadap Potensi Taman Buru Gunung Masinggit Kareumbi, Jawa Barat untuk Pengembangan Ekowisata. Departemen Konservasi Sumberdaya Hutan Fakultas Kehutanan. Universitas Kuningan. Jurnal Ilmu Kehutanan VI (1).

Iskandar, Entang. 2007. Habitat dan Populasi Owa Jawa (Hylobates moloch AUDEBERT, 1797) di Taman Nasional Gunung Halimun-Salak Jawa Barat. Disertasi program Primatologi Sekolah Pasca sarjana Institut Pertanian Bogor.

Faridah, Idah. 1999. Studi Prilaku dan Habitat Jaralang (Ratufa bicolor bicolor) di Hutan Tanaman Pinus Taman Buru Masigit Kareumbi Bandung Jawa Barat Skripsi. Jurusan Sumber Daya Hutan Fakultas Kehutanan Institut Pertanian Bogor.

Febriyanti, Nisa, Syachera. 2008. Studi Karakteristik Cover Lutung Jawa (Trachypithecus cristatus, geoffroy 1812) di Blok Ireng-Ireng Taman Nasional Bromo Tengger Semeru Jawa Timur. Skripsi Departemen Konserpasi Sumber Daya Hutan dan Ekowisata Fakultas Kehutanan Institut Pertanian Bogor.

Fitriani, Y. 2006. Populasi, Distribusi dan Habitat Lutung Jawa (Trachyphitecus Auratus Robinson dan Kloss, 1919). Di Hutan Kawah Putih dan Brussel Gunung Patuha, Ciwidey, Jawa Barat. Skripsi, Jurusan Biologi FMIPA Universitas Padjadjaran

Fuadi, Zainal, D. 2008. Perbandingan Aktivitas Harian Lutung Jawa (Trachypithecus auratus) di Pusat Penyelamatan Satwa (PPS) Petungsewu dan Suaka Marga Satwa Dataran Tinggi Hyang. Skripsi. Jurusan Biologi. Universitas Islam Negeri Malang. 
Hendratmoko, Yohan. 2009. Studi Kohabitasi Monyet Ekor Panjang Dengan Lutung di Cagar Alam Pangandaran Jawa Barat. Tesis Sekolah Paska Sarjana Institut Pertanian Bogor.

Http://gembiralokazoo.com/uploads/093831_2 0110415_lutung\%20jawa.jpg diakses pada tanggal 13Agustus 2012.

Irawan, Adhi. 2011. Aktivitas Tingkah Laku Harian Lutung Merah Jantan (Presbytis rubicunda) pada Siang Hari di Penangkaran. Skripsi. Institut Pertanian Bogor.

Kumar dan Solanki. 2008. Penduduk Status dan Konservasi Langurs Capped (Trachypithecus pileatus) di Dalam dan Sekitar Pakke Suaka Margasatwa, Arunachal Pradesh, India. Jurnal konservasi primata (23): 97-105.

Latifah, Anita. 2002. Studi Populasi dan Distribusi Lutung Jawa di Resort Cibodas, Taman Nasional Gunung GedePangrango, Jawa Barat.Skripsi. Jurusan Biologi Fakultas Ilmu Pengetahuan Alam. Universitas Padjadjaran.

Liu, Wenting, Chengming, Huang, Christian, Roos, Qihai, Zhou, Youbang, Li, Wei, Fuwen.2008. Identifikasi Asal, Spesies dan Jenis Kelamin Lutung (Pygathrix $s p$ ). Vietnam Journal of Primatologi (2008) 2, 63-69.

Nijman V., dan Jatna Supriatna. 2008. The IUCN Red List of Threatened Spesies. [online]. http:// www. iucnredlist. org/ details/22034/0. diakses pada tanggal 24 juli 2012.

Nugraha, Ramdan. 2011. Aktivitas Harian Lutung Jawa (Trachypithecus auratus sondaicus) di Kebun Binatang Tamansari Bandung. Skripsi. Jurusan Biologi Fakultas Sain dan Teknologi Universitas Islam Negri Bandung.

Nursal, Ikbal, Wim. 2001. Aktivitas Harian Lutung Jawa (Trachypithecus auratus, Geoffroy 1812) di Pos Selabintana Taman Nasional Gunung Gede Pangrango Jawa Barat. Skripsi. Jurusan Konservasi Sumberdaya Hutan Fakultas Kehutanan. Institut Pertanian Bogor.

Permadi, Galih, Satrio. Penggunaan Vegetasi Sebagai Habitat Lutung Jawa (Trachypihtecus auratus sondaicus
Robinson dan Kloss, 1919) di Taman Buru Masigit kareumbi Jawa barat. Skripsi Jurusan Biologi Fakultas Sain dan Teknologi Universitas Islam Negri Bandung.

Pratiwi, Ai, Nuri. 2008. Aktivitas Pola Makan dan Pemilihan Pakan Pada Lutung Kelabu Betina (Trachypithecu cristatus, raffles 1812) di Pusat Penyelamatan Satwa Gadog, Ciawi-Bogor. Skripsi Program Studi Ilmu Nutrisi dan Makanan Ternak Fakultas Peternakan Institut Pertanian Bogor.

Prayogo, Hari. 2006. Kajian Tingkah Laku dan Analisis Pakan Lutung Perak (Trachypithecus Cristatus) di Pusat Primata Schmutzer Taman Marga Satwa Ragunan. Tesis. Institut Pertanian Bogor.

Respati, Hari. 2005. Tingkah Laku Pengembaraan dan Aktivitas Harian Kelompok Lutung Jawa di Taman Wisata Alam Pananjung Pangandaran. Skripsi. Jurusan Biologi Fakultas Ilmu Pengetahuan Alam. Universitas Padjadjaran.

Ribby, Affan. 2012. Aktivitas Makan dan Variasi Pakan Lutung Jawa (Trachypithecus auratus sondaicus, Robinson dan Kloss 1919) di Kawasan Taman Buru Masigit Kareumbi Jawa Barat. Skripsi. Jurusan Biologi Fakultas Sain dan Teknologi Universitas Islam Negri Bandung.

Subagio,A. Evid Arfan dan Jodion Siburian 2008. Pola Aktivitas Harian Lutung (Presbytis Cristata, Reffles 1821) di Hutan Sekitar Kampus Pinang Masak, Program Studi Pendidikan Biologi. Jurusan PMIPA, PLIP. Universitas Jambi.

Supriatna J dan EH Wahyono. 2000. Panduan

Lapangan Primata Indonesia. Yayasan Obor Indonesia. Jakarta. http://www.kajia npustaka.com/2012/12/klasifikasi biomorf ologi dan ekologi.html\#ixzz2eShh1i8Y di akses pada tanggal 10 september 2013.

Widarteti., Ai Nuri P, Didit D, dan Anita S T. 2009. Perilaku Harian Lutung (Trachypithecus cristatus, raffles 1812) di Penangkaran Pusat penyelamatan Satwa Gadog, Ciawi-Bogor. Bogor. LIPI. Jurnal biodiversitas 7 (4): 373-377. 